"death-lamp of the Pshaloos" has three wick channels, into which are placed cotton feeds which convey arsenic-impregnated oil from the reservoir: when ignited this lamp fills the death-chamber with arsenical fumes which are toxic to animal life. The composition of the oil shows it to be a compound of dammar, frankincense, white arsenic, and cocoanut oil. Originally intended to protect the "tombtemples" "Pthoi" of the Pshaloos from the ravaging hand of " grave-snatchers," it gradually passed over to more murderous uses. The idea that "East is East and West is West, and never the twain shall meet" is a mere poetical flight of fancy.

In these days of rapid transit and racial intermixture, the possibility of destroying life by littleknown methods must be borne in mind.

I am, Sir, yours faithfully,

Clarence Writret, F.R.C.S. Edin.

Leytonstone, July 10th, 1922.

\section{THE SKULL OF SIR THOMAS BROWNE.}

\section{To the Editor of THE LANCET.}

SIR,-It may be known to some of your readers that the skull of Sir Thomas Browne has recently been reinterred at Norwich, but that previously it came up to London, where careful measurements, drawings, and tracings of it were made. It is proposed to publish a full account of the skull in Biometrika, but it would much add to the interest of the proposed monograph if it were accompanied by a series of reproductions of the portraits and engravings of one of the most noteworthy of Englishmen who have combined the study of medicine with the pursuit of literature.

The large number of plates required to illustrate adequately the relation of the skull to the portraits renders-under the present conditions of both printing and illustrative work-the appearance of a complete monograph, such as we desire to see issued, very difficult. We propose, therefore, to issue one hundred copies of the monograph at the price of one guinea each, if lovers of Sir Thomas Browne can be found in adequate numbers to subscribe for copies. Will you kindly permit us to appeal through your columns for the names of those who are willing to aid in this scheme for putting on permanent record the physical aspect of the author of the "Religio Medici," who, by that and his other works, has won a unique position in the heart as well as in the mind of every cultured Englishman? Willingness to subscribe may be notified to either of the undersigned.

We are, Sir, yours faithfully,

London, July 12th, 1922

ARTHUR KEITH. Kari Pearson.

\section{NEGLIGIBLE GLYCOSURIA.}

\section{To the Editor of THE LANCET.}

SIR,-All agree that no case of glycosuria should be treated as negligible glycosuria until that diagnosis is fully established. About other matters there is a diversity of opinion to a great extent because there is no agreement upon definition. Who can define glycosuria? If one were to assert that glycosuria existed when the urine contained more than $x$ per cent. of dextrose, another would say: "No, not until it contained $(x+y)$ per cent." ; whilst yet another would say " $(x-z)$ per cent. is the limit of normal." The same applies to maximum normal blood sugar, low renal threshold, early mild diabetes, and many of the matters referred to by Dr. P. J. Cammidge and Dr. George Graham in their letters of July 15th. For the moment let us set aside these academic questions, which cannot be decided by mere assertion however dictatorially expressed, but only by vote at an International Congress. "Normal" means "average," and it is a matter of convention as to what variation from the average is to be included in arriving at an average. All have recognised that some glycosurics enjoy perfect health whilst not restricting their diet in any way, and that the condition may persist for 20 years or more. Upon examining some number of these with long histories of glycosuria I found-as others had found-that they possess one peculiarity-namely, that of low renal threshold for dextrose, and no hyperglycæmia. I concluded that anyway some of the individuals with this peculiarity had a negligible glycosuria. It remains to be seen whether the peculiarity predisposes to diabetes mellitus. I am of the opinion that it does not.

Dr. Cammidge writes (THE LANCET, July 15th, p. 150): "Negligible glycosuria, if it is truly negligible never turns into diabetes." If Dr. Cammidge worked at a large hospital he would know how ill-advised it is to use the word "never" when referring to any medical matter, but on this occasion he is simply uttering a platitude. I venture to think that if any useful purpose is to arise from debate great care must be taken in the choice of terms and accuracy of quotations. My assertion was that negligible glycosuria did not protect from diabetes mellitus, which is quite different. If Dr. Cammidge's scorn about this means anything, it must mean that he has discovered some form of glycosuria which does protect from diabetes mellitus. I trust that his evidence of this will be more convincing than the single case which he records at the end of his lettera case of glycosuria without hyperglycæmia, which he asserts was a diabetic. He admits that it can be interpreted in two ways and is only evidence in favour of his view because he thinks it is. I do not admit that $I$ have written anything which justifies him in concluding that I divide all glycosurias into negligible glycosuria and diabetes mellitus; but he may conclude that I divide glycosurias into glycosurias with hyperglycæmia and glycosurias without hyperglycæmia.

Dr. Graham says that according to my definition he would be a case of diabetes mellitus because his blood sugar rises to 0.19 per cent. I did not mean to convey that impression. The limit of blood sugar after a meal containing a fair amount of carbohydrate $(75 \mathrm{~g}$.) to 0.15 per cent. was made only for the diagnosis of glycosuria without hyperolycæmia, in order to be on the safe side, and was admittedly arbitrary. When a congress agrees upon the maximum normal blood sugar, many factors will have to be defined. For instance, the form of carbohydrate in the preceding meal; the ratio of dose to the weight of the individual ; the ratio of the dose to the surface of the individual : the state of mind of the individual during the test; the volume of fluid; muscular activity, \&c. It is because there are so many factors that it is $\mathrm{my}$ view at present that the usual meal is better than a definite weight of dextrose.

Dr. Graham raises a question which did not occur to me-namely, that some mild cases of glycosuria with hyperglycæmia are negligible. Probably there are some, but since I am not acquainted with the means he uses for recognising that the disease would not progress even if hyperglycæmia were allowed to persist I should at present advise a diet to prevent hyperglycæmia, and therefore not term the condition "negligible," perhaps through ignorance.

I am, Sir, yours faithfully,

Portland-place, W., July 17th, 1922. O. LEYTON.

\section{THE " RADIOLOGIST" AND THE "RADIOGRAPHER."}

To the Editor of THE LANCET.

SIR,-In your issue of July 8th you print an editorial article under the heading of the Radiographer on Trial. I turned to it, expecting to find some remarks upon those responsible for carrying out the purely technical side of $X$ ray work, but found that the medical expert and not the technician was referred to. I feel sure, Sir, that this is a slip on your part 
as about a year ago you published an editorial note upon the Society of Radiographers. $\Lambda$ bout that time it was explained in various medical journals that this society had been formed to organise training and examinations for non-medically qualified persons who desired to fit themselves to do $\mathrm{X}$ ray work under medical direction. The British Association for the Advancement of Radiology and Physiotherapy (the "B.A.R.P.") took a large share in the founding of this society; and its constitution, before it was legally incorporated, was submitted to, and approved by, the General Medical Council. This society has held two examinations-the first in January last; the second just completed. Successful candidates have the right to use the letters "M.S.R.," and naturally, and quite correctly, they refer to themselves as " radiographers."

The B.A.R.P., in helping to start the society, were fully aware that the term " radiographer" would be used by its members, and therefore advised all medical men specialising in $X$ ray work to adopt the term " radiologist." This has been to a large extent done, but it would help greatly if medical journals of the standing of THE LANCET would maintain this distinction. The relationship between the radiologist and the radiographer is much the same as that between the oculist and the optician, and it is very desirable that the difference in the meaning of the two terms should be appreciated both by the profession and the public.-I am, Sir, yours faithfully,

F. Hernaman-Johnson, M.D., Joint Hon. Secretary, B.A.R.P.

66, Harley-street, W., July 17 th, 1922.

\section{OPTIC NEURITIS IN MYOPIA.}

\section{To the Editor of THE LANCET.}

SIR,-In discussing a paper on optic neuritis by Mr. Leslie Paton at a recent meeting of the Ophthalmological Society, Mr. Cyril Walker asked for an explanation of the rarity of optic neuritis in myopia. Mr. Paton's reply was to the effect that: (1) the alleged rarity is not a fact ; (2) there can be no reason for it ; (3) myopes are just as liable as anyone else to optic neuritis; and (4) he was at a loss as to how the superstition arose.

I believe that I must plead guilty to having started this "superstition" in a paper read before the Harveian Society of London on Nov. 6th, 1890,1 although others ${ }^{2}$ have the priority in pointing out its converse-viz., the peculiar liability of hypermetropes to optic neuritis.

Mr. Paton's observation that myopes are just as liable to optic neuritis as anybody else is contradicted by my clinical experience and that of others. For more than 30 years I have been on the look-out for cases of optic neuritis in myopia and have not found one amongst my hospital or private patients, though I have been shown one or possibly two by others. This evidence is weak in that it is negative; moreover, my experience has been limited practically to special, that is to say, ophthalmic, hospitals, so that I have not had the same opportunities of coming across such cases as may arise in a general hospital or hospital for nervous diseases. Something more than a statement to the contrary, however, is required to convince me that the combination is not an extremely rare one, and I still hold the view that optic neuritis is commonest in hypermetropia and rare in myopia, the emmetrope occupying a middle position, although I am no nearer an explanation of the causes of the rarity in myopia.

I am, Sir, yours faithfully,

$$
\text { RAYNER D. BATTEN. }
$$

Harley-street, W., July 12 th, 1922 . 'Some Points of Relationship of the Eye to the Cardio-
vascular System, THE LANCET, 1891, vol. i., pp. 984 and 1035. 2 Saundby: Note on Optic Neuritis in Children, Birmingham Med. Rev., 1885. Gowers: Medical Ophthalmoseopy, p. 85
Stevens: New York Med. Ree., August, 1876.

\section{attedical afteros}

Royal College of Surgeons of England.A quarterly Council was beld on July 13th, Sir Anthony Bowlby, the President, being in the chair. The President announced that at a meeting of the Fellows on July 6 th for the election of three Fellows into the Council in the vacancies accasioned by the retirement in rotation of Sir Charles Ballance, Sir William Thorburn, and Mr. W. Mc Adam Eccles, Sir Charles Ballance and Sir William Thorburn were re-elected, and Mr. Robert Pugh Rowlands was elected into the Council.-The President further stated that 814 Fellows had voted, 807 sending their ballot papers through the post, and 7 voting in person, and that the result of the poll was as follows :-

$\begin{array}{lccccc}\text { Sir William Thorburn } & \ldots & \ldots & 502 & \ldots \ldots & 57 \\ \text { Sir Charles Alfred Ballance } & \ldots & 436 & \ldots \ldots & 10 \\ \text { Robert Pugh Rowlands } & \ldots & \ldots & 280 & \ldots \ldots & 39 \\ & & & & & \\ \text { William McAdam Eccles } & \ldots & \ldots & 272 & \ldots \ldots & 17 \\ \text { Victor Bonney } & \ldots & \ldots & 228 & \ldots \ldots & 15 \\ \text { John Herbert Fisher } & \ldots & \ldots & 207 & \ldots \ldots & 30\end{array}$

Sir Charles Ballance, Sir William Thorburn, and $\mathrm{Mr}$ Rowlands were introduced, made declarations in terms of the oath prescribed by the Charter of 1800, and took their seats on the Council.--A report was read from the Board of Fxaminers in Anatomy and Physiology for the Fellowship, stating that at the examination concluded on June 16th 168 candidates were examined, of whom 46 were approved and 122 rejected. The names of the successful candidates have already appeared in THE LANCET.-A report was read from the Board of Examiners in Dental Surgery respecting candidates found qualified for the Licence in Dental Surgery, and licences were granted to the following 64 candidates:-

V. St. J. Alexander and J. F. Allin, Guy's; Fanny H. Bachrach and H. D. Bacon, Royal Dentá ; A. Ball, London; R. Bangert, Royal Dental : C. V. T. Baugh, Guy's ; G. Best, Bir N. S. Campbell, J. H. R. Creasy, and B. Crisp, Guy's W. G. Daniels, Royal Dental; I. S. de V. du Toit, Guy's W. J. Eason, Univ. Coll.; G. H. Edwards, Birmingham J. C. Faure and T. F. Fox, Guy's ; A. E. Fyffe, Sheffield A. A. Gomes, Ceylon and Royal Dental; A. V. Goodson, Guy's ; T. L. C. Gregory, Royal Dental : W. C. Griffiths Birmingham ; W.J.Hide, Guy's , H. Hil, R. Hopkins, and J. Houlton, Royal Dental; J. U. Human and $k$. J. Joels, Guy's ;. L. C. Jones, Liverpool; P. Lloyd-Williams, Royal Dental; E. M. D. Mackie, A. A. R. Madgwick, G. M. Mew, and H. F. Miles, Guy's; Royal Dental ; B. R. Moore, Guy's ; S. F. Parker, Royal

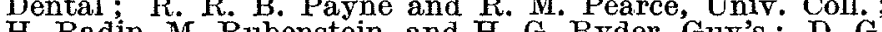
H. Radin, M. Rubenstein, and H. G. Ryder, Guy's; D. G. Saile, Univ. Coll. ; C. P. C. Sargent, H. V. R. Sellers, K. G. Sharvill, and G. L. Shearar, Guy's ; C. J. C. Smal and Anne M. Stephens, Royal Dental ; D. J. Stofberg Guy's; T. N. Strange, Univ. Coll.; V. L. Sunderland and L. N. Theron, Guy's; C. W. F. Thomas, London; W. G Travis, Univ. Coll.; E. A. van Dyck, Royal Dental; R. van Geuns, Guy's; M. Vaughan, Royal Dental; Walravine J. Verheyden, Univ. Coll.; H. Walker, C. W. Woolley, Bristol.

A report was read from $M r$. F. G. Hallett, secretary to the Conjoint Examining Board of Fnoland, respecting candidates found qualified for the Diploma in Public Health, and diplomas were granted to the following 25 candidates mentioned in the report jointly with the Royal College of Physicians: $\rightarrow$

J. E. Bowen, Dublin and King's Coll. ; D. S. Brachman, Pennsylvania and St. Bart.'s; B. C.'Dasgupta, Calcutta and Univ. Coll.; P. Davies, Edinburgh and Cardiff A. M. El Kirdany, Cairo, Glasgow, and Guy's; R. F' Fagan, Univ. Coll.; C. H. H. Harold, Liverpool and R.A.M. Coll.; P. A. Hayne, St. George's; F. B. Hobbs, Cam bridge and Univ. Coll.; C. B. Hogg, Aberdeen and Royal Inst. Pub. Health; $A$. E. Ironside, Middlesex ; Doris E. P. Jolly, King's Coll. ; B. L. Joshi, Punjab and Royal Inst Madhok, St. Ándrews and Univ. Coll.; J. Misquitta, Bombay Madhok, St. Andrews and Univ. Coll.; J. Misquitta, Bombay and Royal inst. Pas. Hoalth and Univ. Coll.; G. R. Painton, London and Royal Army Mned. Coll. Barbara Richardson, Edinburgh and Royal Inst. Pub. Health ; . P. Rosha, Punjab and Univ. Coll. A. D. Soares, Bombay and Royal Inst. Pub. Health Ruth C. Townsend, Royal Free and Univ. Coll.; J. R. D Wiltshire, Cambridge and King's Coll. ; and F. H. Young. Cambridge and St. Bart.'s.

A report was also read from Mr. Hallett respecting candidates found qualified for the Diploma in Psychological Medicine, and nine diplomas were granted, jointly with the Royal College of Physicians, to the following candidates:J. Bostock, London and Hanwell ; J.J. Gasperine, St. Bart.'s and Horton; H. H. P. Morton, King's Coll. and Bexley: 